〔43〕高分子皮膜の気体透過性

第 1 報 ポリエチレンの密度と気体蒸気の透過性

(1958 年 8 月 11 日受理)

伊 藤 行 雄*

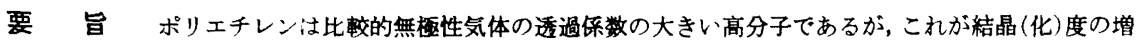
加とともに透過係数は诚少を示す。分忮度による密度の違いと熱処理による密度の違いは透過係数に対してほ とんど同じような効果を与える。窒素の透過係数は非結晶度の約 1 乘に比例する。溶解度係数が窒素に比して 大きいと考えられ，また透過係数の大きな酸素，炭酸ガスは，窒素に比してわずかに大きく，非結晶領域の影 慗を受ける溶解度俰数の大きな有機溶媒蒸気においても，その透過㐿数は非結晶度の約 1.4 乗にしか比例しな い。このことからポリエチレンの透過をおもに支眍するものは非結晶領域における抎散であると考えられる。
\end{abstract}

\section{1. 緒言}

高分子皮膜の透過性を支配する大きな因子としては, 分子量と結晶度が考えられる。しかるに分子量と透過俰 数の関倸については, D.W. Brubaker ら ${ }^{11}$ が炭酸ガス, 水素について有意差はないと報してているが, 結晶度の等 しいものを使ったか,と゚うかは明らかではない。古谷氏2 はポリイソブチレンの水蒸気の透過倸数の分子量依存性 について報告している。また A.W. Myers ら ${ }^{8)}$ はポり エチレンの密度と透過係数の間には単純な関倸はないと 報告しているが, 試料数が僅少であるなどの難点がある。 筆者はポリエチレン, 塩化ピニル"について機械的強度 がほぼ一定になるような分子量以上においては透過係数 には、ほとんど差がないことを確かめ, 分子量 $\left(\bar{M}_{n}\right)=$ 27,000 以上の密度の異なるポリエチレンについて, 密度 と透過係数, 拡散保数, 溶解度俰数の関係空素, 酸素, 炭酸ガス, 水蒸気, 有機浴媒蒸気について測定した。

\section{2. 試料}

分子量 $\left(\bar{M}_{n}\right) 27,000$ 以上のポリェチレンについては, ほとんど透過倸数に差が認められなかったので，第 1 表 に示した樹脂で高圧法ポリエチレンについては， $\bar{M}_{n}$ 27,000 以上のもの, 低压法ポリエチレンについては, $\bar{M}_{\boldsymbol{n}}$ 50,000 以上のものを調製し，熱溶融によって約 $0.1 \mathrm{~mm}$ の皮膜をつくり，それぞれの試料を軟化点付近において 1 時間以上放置して可能な限り成型時の残留ひずみを除 去した。数種の樹脂については泠却速度を変えることに よって結晶度の異なる皮膜を調製した。

\section{3. 測定方法}

\section{1 密度の測定}

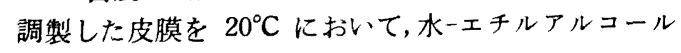
系における浮遊法により測定した。

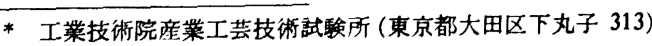

第 1 表 供試ポリエチレン

\begin{tabular}{|c|c|c|}
\hline 記号 & 柄 & 公称密度 \\
\hline A & Tenite 807 & $0.915 \sim 0.92$ \\
\hline \multirow[t]{9}{*}{$\mathrm{B}$} & Alathon 10 & 0.923 \\
\hline & Spencer KA-245-5 & 0.925 \\
\hline & L. C. I. $570 \mathrm{~L}$ & 0.917 \\
\hline & Orizon 306 & 0.92 \\
\hline & Alkathen $4 \mathrm{~F}$ & 0.916 \\
\hline & Lupolen $\mathrm{H}$ & 0.92 \\
\hline & Petrothen & 0.922 \\
\hline & DYNH & 0.92 \\
\hline & DFD0111 & - \\
\hline \multirow[t]{4}{*}{$\mathrm{C}$} & Hizex & 0.95 \\
\hline & Super Dylans & $0.93 \sim 0.95$ \\
\hline & Marlex 50 & 0.96 \\
\hline & Fortiflex & 0.96 \\
\hline
\end{tabular}

\section{2 透週係数の測定}

\section{2 .1 気体について}

Sarge, Cartwright ${ }^{5)}$ と同様な装置で, 圧力差 1 気圧 下で測定を行なった。水銀柱の圧力変化は $1 / 100 \mathrm{~mm}$ の 目盛を有する測微䫓微鏡によって測定した。透過係数 $(P)$ 拡散係数 $(D)$ 溶解度係数 $(S)$ は次式より求めた。

$$
\begin{aligned}
& P=\frac{d p}{d t} \cdot \frac{V}{A} \cdot \frac{l}{76} \cdot \frac{T_{0}}{T} \cdot \frac{1}{p_{0}} \mathrm{cc} \cdot \mathrm{cm} / \mathrm{cm}^{2} \cdot \mathrm{sec} \cdot \mathrm{cmHg} \\
& D=\frac{l^{2}}{6 \theta} \quad \quad \mathrm{cm}^{2} / \mathrm{sec}
\end{aligned}
$$




$$
S=\frac{P}{D} \quad \mathrm{cc} / \mathrm{cm}^{3} \cdot \mathrm{cmHg}
$$

ただし $p$ : 低圧側の圧力, $p_{0}$ : 高圧側の圧力, $V$ : 低圧 側の空間容積, $A$ : 試料の面積, $l:$ 皮膜の厚さ, $T_{0}$ : 標 準温度, $T$ : 実験温度, $\theta$ : 遅九時間

\section{2 .2 水蒸気について}

JISZ 0208 により, 有機溶媒蒸気についてはカップ法 ${ }^{6)}$ によった。この場合の透過係数の単位は $\mathrm{g} \cdot \mathrm{cm} / \mathrm{cm}^{2} \cdot \mathrm{sec}$. $\mathrm{cmHg}$ をとった。ただんロシン，酢酸ブチルの蒸気圧

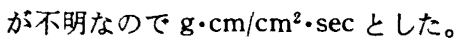

以上の測定において，透過俰数 $P$ は良い再現性を示 すが，拡散係数 $D$ は逢れ時間 $\theta$ によって定まるが， $\theta$ の 測定はバラッキが大きいので，ここでは同一試料につい て 3 回以上の $\theta$ を測定して，そのうちの最大の $\theta$ を用い て $D$ の計算に使用した。なお透過性の測定温度は特別 な場合以外は $25^{\circ} \mathrm{C}$ で行なった。密度の測定温度とわず かの違いがあるが、これは測定結果の考察には大きな影 鄉を及ぼさないと考えられる。

\section{4. 測 定結 果}

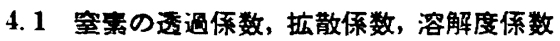

A， B，C試料を急冷（高温よりただちに液体空気中に 投入)，徐冷などによってつくった密度の異なる試料の $P, D, S$ と密度の逆数との間係を第 1 図に示した。3 種

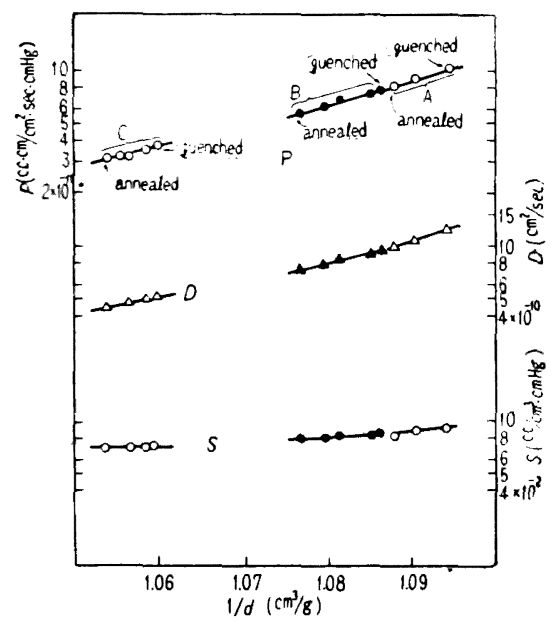

第1图異なる比容積のポリエチレン 皮膜の空素透過性 (I)

の試料のいずれについても透過係数 $P$ の対数傎と密度の 逆数 $1 / d$ (すなわち比容積)の対数值の間には 1 次関倸が

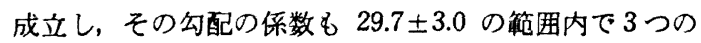
試料もおさまる。拡散係数, 溶解度釈数についても同様 に 1 次関係が成立する。溶解度係数については試料の差 が現われてくる。広箷囲な密度と気体透過性の関係を求

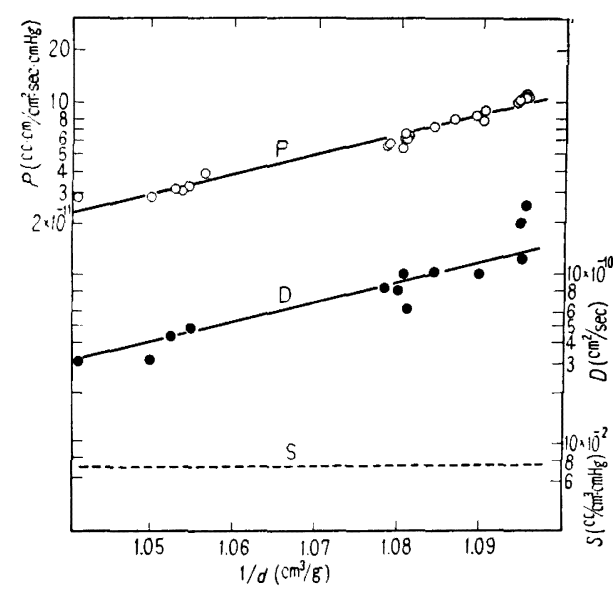

第 2 図 ポリエチレンの皮膜の窒素透過性 (II)

めるために第1表にかかげた試料の比容積と窒素の $P, D$ および $S$ の関係を第 2 図に示した。高密度ポリエ チレンの測定值はややバラックが, それにしても $\log P$ と $\log 1 / d$ との相関関係は $r^{2}=0.92$ で比例関釈が成立す る $(r$ : 相関係数)。Dについても同様であるが, $S$ につい てはPほどよい相関を示さないので点線をもってその傾 向を示した。

\section{2 酸素, 炭酸ガスの透週係数}

酸素，炭酸ガスの $\log P$ と $\log 1 / d$ の間にもきれいな 直線関係が成立する。ただ窒素, 酸素, 炭酸ガスの順 に従って, 勾配の倸数は $29.3,35.5,38.8$ と增加の傾向 にある。なお酸素、炭酸ガスの $D, S$ は遅九時間が短く, 誤差が大きくなるので,ここでは示さなかった。

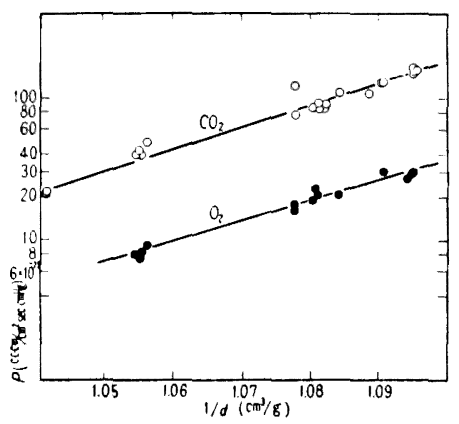

第 3 图 ポリェチレン皮膜の酸素, 炭酸 ガスの透過係数

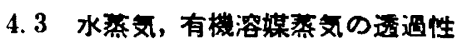

水蒸気については第 4 図に示した。ク口ロホルムのP, $D$ ，および $S$ にいては第 5 図に示した。カップ法によ る $\theta$ の測定は気体の測定以上に困難であるが, (4), (5)式 と同様に考えて，それぞれ $D, S$ を求めた。ケロシン， 


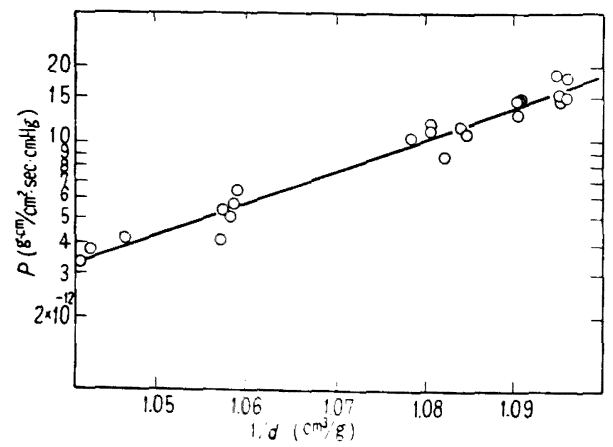

第 4 図 ポリェチレン皮膜の水蒸気透過倸数

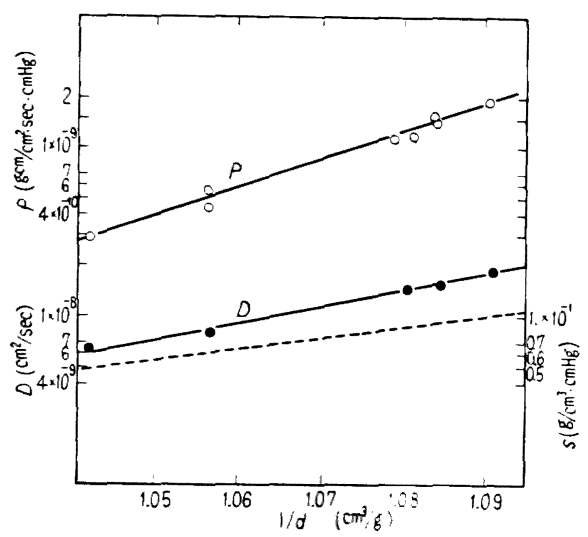

第 5 図ポリエチレン皮膜のクロロホルムの透過性

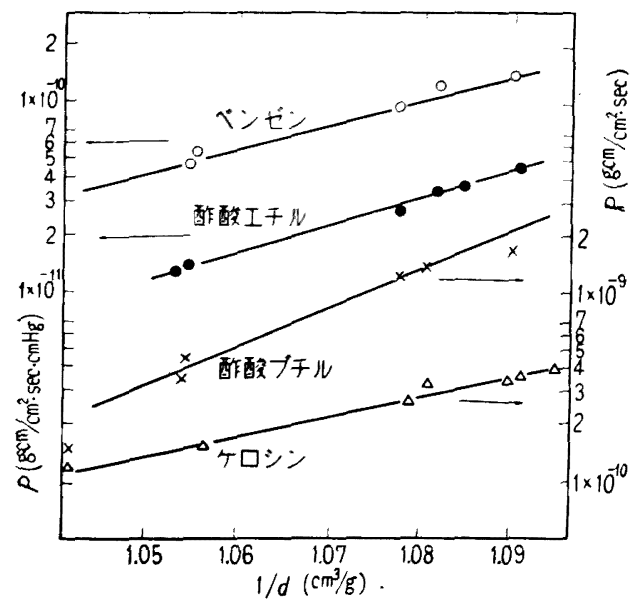

第 6 図ポリエチレン皮膜の有機溶媒

蒸気の透過係数

ヘンぜン, 酢酸エチル, 酢酸ブチルについてのPと比容 積の関係は第 6 図に示した。

\section{5. 考察}

\section{1 密度と透週係数, 拡散係数の関係}

第 1〜6 図から透過係数 $P$, 拡散俰数 $D$ と密度の間に次 式が実験的になりたつ

$$
\begin{aligned}
& \log P=m \log \left(\frac{1}{d}\right)+b \\
& \log D=m^{\prime} \log \left(\frac{1}{d}\right)+b^{\prime}
\end{aligned}
$$

しかるに密度と非結晶化度 (Amorphous content) の間 には一定の関係があることが知られている7゙。その中で 異なる重合条件によってつくられたポリェチレンについ ては, 広い密度節囲の D.C. Smith ${ }^{8}$ の報告がある。これ によって非結晶化度の換算を行ない, 非結晶(化) 度 $(\alpha)$ と $P$ および $D$ の関倸を第 7 図に示した。この図からこ

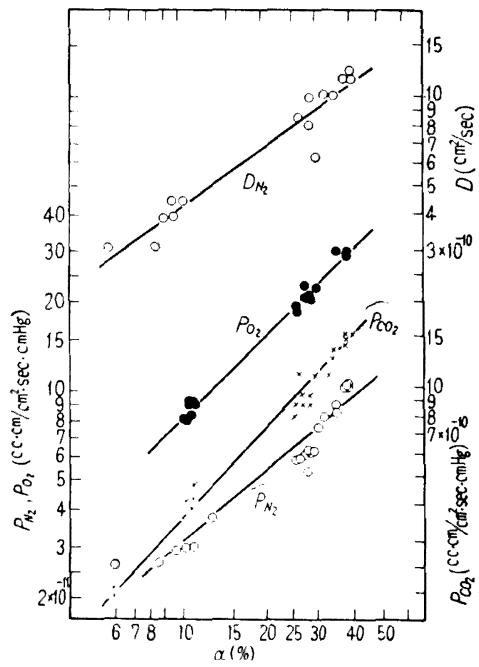

第 7 図 ポリェチレンの非結晶度と 透過係数，拡散係数

れらの間に次の関倸がなりたつものと考え

$$
\begin{aligned}
& \log P=n \log \alpha+\beta \\
& \log D=n^{\prime} \log \alpha+\beta^{\prime}
\end{aligned}
$$

(5)式から $n$ の值を求めて第 2 表に示した。これから $P$ は $\alpha$ の約 1 乗に比例するものと考えても大きな誤りには ならない。無極性気体は窒素, 酸素, 炭酸ガスの順序に 従って, $n$ も 0.84, 0.97，1.06 と大きくなっている。ま た窒素の $D$ もポリエチレンの非結晶度の約 1 乗に比例し ている。このことは拡散がほとんど非結晶領城で行なわ れ, 結晶領域では昖散はほとんど行なわれないと考えら れる。また $P$ が同様に非結晶度の1乗に比例するとい5 ことはポリエチレンの透過現象が，ほとんど拡散に支配 されていると考えたい。また案素, 酸素, 炭酸ガスの差も この順に従ってPが大になり，またコムなどの溶解度係 
第 2 表 ポリエチレンの透過係数

\begin{tabular}{|c|c|c|c|c|c|}
\hline 気体または蒸気 & $\begin{array}{c}\text { 測定温度 } \\
\left({ }^{\circ} \mathrm{C}\right)\end{array}$ & $\begin{array}{c}P \times 10^{11} \mathrm{cc} \cdot \mathrm{cm} / \mathrm{cm}^{2} \cdot \mathrm{sec} \cdot \mathrm{cmHg} \\
1 / d=1.0900\end{array}$ & $m$ & $n$ & 備 \\
\hline $\mathrm{N}_{2}$ & 25 & 9.2 & 29.3 & 0.84 & \\
\hline $\mathrm{O}_{2}$ & 25 & 26.5 & 35.5 & 0.97 & \\
\hline $\mathrm{CO}_{2}$ & 25 & 124.0 & 38.8 & 1.06 & \\
\hline $\mathrm{O}_{2}$ & 23.8 & 28 & 32.4 & 0.92 & 12) \\
\hline $\mathrm{He}$ & 23.8 & 58 & 29.5 & 0.84 & \\
\hline $\mathrm{H}_{2}$ & 23.8 & 88 & 32.6 & 0.92 & \\
\hline $\mathrm{C}_{2} \mathrm{H}_{6}$ & 23.8 & 143 & 52.0 & 1.42 & \\
\hline $\mathrm{CH}_{3} \mathrm{Br}$ & 30 & 1,900 & 55.4 & 1.43 & 3) \\
\hline $\mathrm{H}_{2} \mathrm{O}$ & 40 & 1,744 & 30.3 & 0.91 & \\
\hline ケロシン & 25 & - & 25.6 & 0.73 & \\
\hline 酢酸エチル & 25 & 1,000 & 36.6 & 1.01 & \\
\hline 酢酸ブチル & 25 & & 35.5 & 1.38 & \\
\hline クロロホルム & 25 & 27,500 & 41.4 & 1.13 & \\
\hline ベンゼン & 25 & 38,900 & 30.7 & 0.87 & \\
\hline
\end{tabular}

数がこの順に大きいからポリエチレンの溶解度係数もこ の順と考えられるから，溶解度の因子が少しずつ影響し ているものと思われる。 水蒸気が大なるPを有しているにかかわらず，比例次 数が小さいのは, (1) $40^{\circ} \mathrm{C}$ RH $90 \%$ に長時間保持する ことが困難なため測定值がバラッキ，測定誤差が大きく なる。(2) $P$ の測定温度が $40^{\circ} \mathrm{C}$ にかかわらず, 密度の測 定温度が $20^{\circ} \mathrm{C}$ であるためによる非結晶度の換算が少し 当を得ていない。(3) 窒素, 酸素などの溶解熱は $2 \mathrm{kcal} /$ $\mathrm{mol}^{13)}$ にすぎないのに，水蒸気のポリエチレンに対する 溶解熱は $11 \mathrm{kcal} / \mathrm{mol}$ で示されるように特異的であるな どが原因と考えられる。クロロホルムのような溶解度の 大きな有機溶媒蒸気でも $n$ の值は 1.14 で $n^{\prime}$ は 0.74 で あるから透過の主力は昖散であるといえる。D.C. Smith" ${ }^{97}$ の密度から非結晶度の換算值は他の報告》 に比 して小さいにかかわらず, よい相関を示すから, 結晶領 域仪近い非結晶部分は無極性気体の透過現象にあまり関 与しないものと考えられる。また有機溶媒蒸気になると これらの領域においても溶解が多少は起り, 拡散, 透過 が行われるものと考えたい。なお第 1,2 四から分岐度に よる密度の違いと熱処理による密度の違いは透過に対し てほとんど同じような効果を与えるものと考えられる。

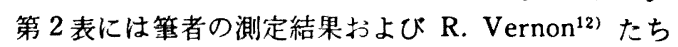
の測定值について(4), (5)式によって, 気体, 蒸気の $m$, $n$ を求めて示した。気体, 蒸気の極性の有無による差異 については興味ある問題であるので別に報告することと して,これらの一括した值をみると $n$ は $0.7 \sim 1.4$ の範围
におさまる。溶解度倸数の小さい無極性気体については $P$ は $\alpha$ の約 1 乗に比例し, 高密度ポリェチレンのP の減 少は抎散効果に起因する。 $S$ の大きいと考えられる気体 は非結晶領域に溶解しやすく，透過の主因は拡散であっ ても， $S$ の項が若干きいてくる結果， $n$ も大きくなり， $P$ が大きくなるものと思われる。

ポリエチレンの結晶度が $0(\%)$ のものを仮定して窒素 の $P$ を計算してみると, $25 \times 10^{-11}$ となり, 天然ゴムの $80 \times 10^{-11}$ と比較して，大体妥当な值と考えられる。

\section{2 密度と溶解度係数}

窒素について第 2 図に示したごとくわずかしか密度の 影響を受けず, ポリエチレンに対してかなりの溶解度を 有するクロロホルムにあっても, 非結晶度の約 0.5 乗に

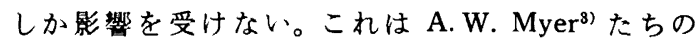
$\mathrm{CH}_{8} \mathrm{Br}$ の吸着測定值を検討しても同様であり，溶解度倸 数は拡散保数ほど密度の影響を受けない。ただここであ げた溶解度係数 $S$ は (3)式で計算されたものであるから， それについて検討してみると

\section{2.1}

第 1 図で示した窒素の $S$ は天然ゴム帛の $S 0.056 \mathrm{cc} /$ $\mathrm{cm}^{8} / \mathrm{atm}$ に比してかなり大きい。これは前述のごとく 遅れ時間の測定は再現性が悪いので, 最大の遅れ時間を とって $D$ を計算し，その $D$ から $S$ を計算する結果， $S$ は大きく出る。ポリェチレンの遅れ時間の測定值は非常 に少ない ${ }^{00}$ のもこの理由からと考えられる。

\section{2.2}

(3)式からの $S$ の值と吸着法による $S$ の値とは必ずし 
も一致しない。筆者が今まで単純に表わしている $D$ は むしろ, 見かけ111) の拡散係数であって次の $\bar{D} に$ 相当す るものである。

同様に $S$ \&

$$
\bar{D}=\frac{1}{c} \int_{0}^{c} D d c
$$

$$
\bar{S}=\frac{1}{p} \int_{0}^{p} S d p
$$

と考えるべきである。また(2),(3) 式は Fick law の特別 解であって, 筆者の測定方法が特別解の条件を十分に満 足しているかどうかは不明である。

\section{2.3}

$S$ の計算式としては(3)の外に Courant-Hilbert の方 法がある。これに測定値を入れて計算しても, 良い一致 を示さないことがある(4)。

以上の点から (3) 式から求めた $S$ には問題があると思 われるが,ここでは同じ測定方法で, ほとんど同じ厚さ の皮膜についての測定結果を比較しているのであるか ら, 密度と溶解度俰数との関係を述べるにはさしつかえ ないと思う。

\section{6. 結 言}

密度の異なるポリエチレン皮膜の透過係数の測定結果 加ら $\log P=m \log (1 / d)+b$ の関係が認められ, 密度と非 結晶度の換算から, 溶解度の小さい無極性気体のP $P$ は非 結晶度の約 1 乗に比例し, 溶解度の大きい気体, 蒸気の $P$ 注わずかばかり，それ以上に大体比例する。同様に $D$ も非結晶度の約 1 乗に比例すると考えられるから, ポリ エチレンの透過を支配するものは，拡散であり，とくに
窒素などの無極性気体においては拡散がほとんどであ り，透過は主として非結晶領域で行なわれることを推論 した。

付 記：研究にあたりご教示いただいた東京工大井上幸 彦教授，当所福岡部長に厚く謝意を表する。本研究は化学関連 学協会秋季研究連合発表会 (昭和 32 年 11 月東京) に招いて報告 した。

\section{文献}

1) D.W. Brubaker and K. Kammermeyer: Ind. Eng. Chem., 45, 1148(1953)

2) 古谷進: 高化, 12, 139(1955)

3) A.W. Meyers et al: Mod. Plast., 34, 157 (May, 1957)

4) 伊藤行雄: 高分子大会請演 (昭和 33 年 6 月)

5) T.W. Sarge: Ind. Eng. Chem., 16, 396(1944); L.L., Cartwright: Anal. Chem., 19, 393(1947)

6) J. Julespinsky: Mod. Pack., 28, 12, 145(Aug, 1954)

7）たとえば C.A. Sperati et al：J. Am. Chem. Soc., 75, 6127 (1953) ; R.B. Richards : J. Appl. Chem., 1, 370(1951)

8) D.C. Smith: Ind. Eng. Chem.: 48, 1161 (1956)

9) たとえば G.J. Van. Amerongen: J. Appl. Phys., 17, 972(1946)

10) 武田文七：日本化学会年会講演 (昭和 33 年 4 月)

11) I. Sobolev, et al: Ind. Eng. Chem., 49, 441 (1957)

12) R.J. Vernon: Ind. Eng. Chem., 48, 1160(1956)

13）伊藤行雄：未発表, 続いて投稿の予定

14) Courant-Hilbert: Methoden der Mathmatishen Physik, 63 (Julius Springer (1931))

\title{
Permeability of Gas and Vapor in High-polymer-film
}

\section{The Effect of Density on the Permeability of Polyethylen}

\author{
By Yukio Ito*
}

\begin{abstract}
The Permeability constants of various polyethylen to nitrogen, oxygen, carbondioxid, water vapor and organic vapors were examined. Linearity could be found between $\log P$ and $\log \alpha$ : where $P$ is permeability constant, and $\alpha$ is amorphous content. $P$ and $D$ (Diffusion constant) to nonpolar gas like nitrogen are aproximately proportioned linearly to amorphous content, but $S$ (Solubility constant) somewhat changes in proportioned to amorphous content. $P$ to water vapor and organic vapors are aproximately proportioned linearly to amorphous content as well. In consequence, I decieded that permeation of gas and vapor through polyethylen take place in amorphous part and mainly depend on diffusion.
\end{abstract}

* Industrial Arts Institute (Shimomaruko, Ōtaku, Tokyo) 